\title{
Biomechanical study for stride length of pull-resisted and un-resisted run of acceleration phase for youth $100 \mathrm{~m}$ sprinters \\ *Dr/ Mohammed Suleiman Salam Salem
}

\section{Introduction and research problem}

Sprint running is an event of specific biomechanical variables, although it based on genetic aspects, that are associated with the characteristics of the muscle fiber and its rapid contraction ability, besides the anatomical body structure, still the runner is able to enhance the technical performance, in other word, learning the correct running biomechanics and introduce some exercises that help the rapid muscle contraction to continue in the production of anaerobic energy. Therefore, sprint biomechanical variables should be consider in order to provide ideas that may positively influence the sprint running, and instructions of selecting appropriate exercises.

María-Asunción

Martínez (2015) et al. believes that although it is common sprint training practice to use maximal strength exercises, vertical jumps and their derivatives, it has been postulated that a more specific training method for sprinting would use horizontal force production in unilateral movement, such as sled towing or resisted sprinting. Ideally, athletes using sled towing should imitate the range of motion, body position, muscle activation time, and sprint velocity near the running speeds used in competition. (9:140)

According to Jürgen Schiffer (2009), adopted from Coh \& Tomazin, and Frye, for sprinters, muscle power, neurological innervations, and length of limbs are the most important factors to consider. These factors affect the two main components that determine running velocity: stride length and stride frequency.Stride length is governed by the power the sprinter exerts during the

* the Department of theories and application track and field events, Faculty of Physical Education- Zagazig University 
ground contact period. Stride length in turn has an effect on the angle of force to the ground( $(?: 9)$.

\section{Research problem :}

Loren Seagrave (2012)

highlighted that pure acceleration phase is the first of two links between the initial movement of the start and maximum velocity sprinting. Transition Phase serves as the Neuro-Mechanical Link between Acceleration and Vmax. Duration to Reach 95\% of Vmax for Elite is 4.5 to 5.0 Seconds( $\varepsilon)$.

The researcher finds that coaches use resistance exercises to develop running velocity either by using traditional resistance drills (heavy loads) for developing force or merging maximum strength training with polymetric training to develop specific force or strength training with light loads and high velocity to increase force production i.e. pull-resisted run, which develop the efficiency of sprint run to acceleration phase if it is used to a limit that doesn't hinder the running technique.

The researcher supposes that pull-resisted runs develop acceleration phase, in which the runner's rate of velocity gradually increased for the longest possible distance, in other words, picking up acceleration to dilly maximum velocity. Runners pull additional weights (mass), which enable them to store more energy to improve muscle actions, which in turn improve support time and its relation to frequency and stride length in un-resisted run, without negatively influence the running technique. Therefore, the researcher, in this study, identifies the biomechanics of stride length with pull-resisted runs of acceleration phase, and its impact on the technique and velocity.

\section{Research objective:}

The objective of this paper is as follow:

Identifying the biomechanical variables of sprint stride in pull-resisted runs and un-resisted runs and study the differences between them in the acceleration phase of $100 \mathrm{~m}$.

\section{Research question :}

- What are the biomechanical variables of sprint stride for pull resisted 
runs of acceleration phase for sprint junior 100

- What are the biomechanical variables of sprint stride for un pull resisted runs of acceleration phase for sprint junior 100

- What are the differences biomechanical variables between sprint stride for pullresisted un pull resisted runs of acceleration phase for sprint junior 100

Research Procedures:

\section{Methology :}

The researcher used the method descriptive, based on the biomechanical analysis, using computer for its relevance to this study.

Subject athletes:

The researcher selects the purposive sample (6 runners) among $100 \mathrm{~m}$ runners from Talented Athletes School in cairo, who are registered in the Egyptian Athletics Federation (EAF) for the season 2014/2015.

Table (1)

statistical description about the sprinters

\begin{tabular}{|c|c|c|c|}
\hline $\begin{array}{l}\text { Standard } \\
\text { Deviation }\end{array}$ & Arithmetic mean & Measuring unit & Variable \\
\hline 1.9 & $1 V_{.1}$ & Years & Age \\
\hline 0.9 & 189 & $\mathrm{Cm}$ & Length \\
\hline 7.4 & $V \leq . r$ & $\mathrm{Kg}$ & Weight \\
\hline.$\wedge \wedge$ & Y.VT & Years & Training age \\
\hline
\end{tabular}

Table (1) shows the statistical description of the subject runners (height, weight, chronological age, training age and the personal best).

Prospective study :

The researcher conducts a prospective study on Tuesday $12 / 5 / 2015$ on the track of Zagazig University. The study included the following steps:

Video recording preparation: This stage include the following:
- The place was prepared for video recording by putting checkmarks (guidelines) in the background, range of motion and preparing the scale of drawing.

- The author used (2) Cameras of $125 \mathrm{c} / \mathrm{s}$. The cameras were installed on tripods. The researcher was keen to have the vertical axis of the camera's lens 
perpendicular to the sagittal plane.

- The two cameras were placed $15 \mathrm{~m}$ from the starting line, $12 \mathrm{~m}$ apart from each other from the inner edge of fourth lane outside of the track, at a height of $1.27 \mathrm{~m}$.

- Markers were placed as checkmarks along the path of each camera according to the previous division, as well as markers along the start line and another along the finish line.

\section{Basic study :}

The basic study was implemented on Saturday $23 / 5 / 2015$ at $14: 30$ on the track of Zagazig University in the presence of a number of faculty staff, to cooperate with the researcher in the completion of the basic study. The researcher took into account all procedures of the prospective study.

Video recording stage:

\section{Means of data collection:}

- TV imaging and analysis using computer tools:

The researcher used these tools because of its relevance to this study and required data.

Tools, and required equipments in TV imaging shall be presented as follow:
- Two video cameras $125 \mathrm{c} / \mathrm{s}$ (electric battery), with lens to electronically regulate lighting and kinetic analysis system "Simi Motion ."Calibration was done for both cameras.

- 2 Tripod for cameras

- Chekmarks

- Drawing scale $20 \times 20 \mathrm{~cm}$.

- Measuring tape to determine the dimensions of video recording.

- Markers to identify acceleration phase used as guidelines.

- Digital watches to determine the required times.

The researcher has followed the following steps :

- Check the cameras before the start of the race.

- Ensure that there is no deviation or change in the cameras, by using water balance.

- The author was keen to have the cameras' lens vertical axis perpendicular to the spatial level at $30 \mathrm{~m}$ sprint of this study.

- Drawing scale was separately filmed for each camera before the start of the race. Water board was placed in front of each camera's Len by assistants at the front of the cameras, to facilitate photos 
transfer for analysis. The range of motion for camera's Len was $7 \mathrm{~m}$.

- Markers were placed at each $5 \mathrm{~m}$ from the start line.

- A rope $(10 \mathrm{~cm}$ length and 5 $\mathrm{cm}$ width) was hanged at 7.80 $\mathrm{m}$ in a solid ring installed in a solid pole in a tube-shape in a longitudinal texture pocket, well fixed on the runner's backbone. The rope is tightly tied from the center with the sled. The sled is a tube-shape, aluminum made of $10.20 \mathrm{~kg}$ in a rectangular shape $(30 \mathrm{~cm} \times 27$ $\mathrm{cm})$. The weight is placed on the column at the middle of the sled, installed on a net made of sheet $(7 \mathrm{~cm}$ width).
- Each sprinter performs 2 pull-resisted runs, $15 \%$ and $20 \%$ of BM, and 2 un-resisted runs for increased speed of 30 $\mathrm{m}$ sprint for subject runners.

- The best time trial was selected for analysis.

Data Statistical analysis :

- Arithmetic mean and correlation coefficient :

\section{Discussion:}

- Presenting the results of biomechanical variables with and without pull-resisted runs of sprint stride for subject runners.

- Presenting touchdown results (left support) for subject runners

Table (2)

Significant differences of biomechanical variables of un-resisted and pull-resisted runs (15\% $-20 \%$ of $\mathrm{BM})$ in the left front support

\begin{tabular}{|c|c|c|c|c|c|c|c|c|}
\hline \multirow[b]{2}{*}{ Significance } & \multirow[b]{2}{*}{$\begin{array}{l}\text { Sig. } \\
\text { )p.value( }\end{array}$} & \multirow[b]{2}{*}{$\begin{array}{l}\text { Friedman's } \\
\text { test } \\
\text { )X2 ( }\end{array}$} & \multicolumn{3}{|l|}{ Mean } & \multirow[b]{2}{*}{$\begin{array}{l}\text { Measuring } \\
\text { units }\end{array}$} & \multirow[b]{2}{*}{ Variables } & \multirow[b]{2}{*}{$\mathbf{S}$} \\
\hline & & & $\begin{array}{c}\text { Pull- } \\
\text { resisted } \\
\text { runs of } \\
20 \% \\
\text { of } \mathrm{BM}\end{array}$ & $\begin{array}{c}\text { Pull- } \\
\text { resisted } \\
\text { runs of } \\
15 \% \text { of } \\
\text { BM }\end{array}$ & $\begin{array}{l}\text { Un- } \\
\text { resisted } \\
\text { runs }\end{array}$ & & & \\
\hline $\begin{array}{l}\text { Statistically } \\
\text { Significant }\end{array}$ & $\because \cdot r$ & $\checkmark .$. & $\wedge . \wedge \wedge$ & 9.41 & 9.84 & $\mathrm{~m} / \mathrm{s}$ & $\begin{array}{l}\text { Velocity of } \\
\text { the COM }\end{array}$ & 1 \\
\hline $\begin{array}{l}\text { Statistically } \\
\text { Significant }\end{array}$ & $\because+1$ & (T.r & 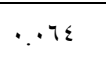 &. .07 & $\because \cdot \sum V$ & $\mathrm{~S}$ & $\begin{array}{l}\text { Time of } \\
\text { touchdown }\end{array}$ & 2 \\
\hline $\begin{array}{l}\text { Statistically } \\
\text { Significant }\end{array}$ & $\because \cdot \varepsilon$ & $7 . r 0$ & rt & ro & $\leqslant 1$ & $\mathrm{Cm}$ & $\begin{array}{l}\text { The } \\
\text { horizontal } \\
\text { distance } \\
\text { between } \\
\text { toe an } \\
\text { COM }\end{array}$ & 3 \\
\hline
\end{tabular}

Follow Table (2)

Assiut Journal For Sport Science Arts 
Significant differences of biomechanical variables of un-resisted and pull-resisted runs (15\% $-20 \%$ of $B M)$ in the left front support (touchdown) $\quad \mathrm{N}=6$

\begin{tabular}{|c|c|c|c|c|c|c|c|c|}
\hline \multirow[b]{2}{*}{ Significance } & \multirow[b]{2}{*}{$\begin{array}{l}\text { Sig. } \\
\text { )p.value( }\end{array}$} & \multirow[b]{2}{*}{$\begin{array}{l}\text { Friedman's } \\
\text { test } \\
\text { )X2 ( }\end{array}$} & \multicolumn{3}{|l|}{ Mean } & \multirow[b]{2}{*}{$\begin{array}{l}\text { Measuring } \\
\text { units }\end{array}$} & \multirow[b]{2}{*}{ Variables } & \multirow[b]{2}{*}{$\mathbf{S}$} \\
\hline & & & $\begin{array}{c}\text { Pull- } \\
\text { resisted } \\
\text { runs of } \\
20 \% \\
\text { of } \mathrm{BM}\end{array}$ & $\begin{array}{c}\text { Pull- } \\
\text { resisted } \\
\text { runs of } \\
15 \% \text { of } \\
\text { BM }\end{array}$ & $\begin{array}{l}\text { Un- } \\
\text { resisted } \\
\text { runs }\end{array}$ & & & \\
\hline $\begin{array}{l}\text { Statistically } \\
\text { Significant }\end{array}$ & $\because \cdot 1$ & Tr & T. ro & $\varepsilon . r$. & $0 . \leqslant V$ & $\mathrm{Kg} / \mathrm{s} 2$ & $\begin{array}{l}\text { Momentum } \\
\text { of the left } \\
\text { arm }\end{array}$ & 4 \\
\hline $\begin{array}{l}\text { Statistically } \\
\text { Significant }\end{array}$ & $\because r$ & איט & A. Ir & $1 . .19$ & Ir.VA & $\mathrm{Kg} / \mathrm{s} 2$ & $\begin{array}{l}\text { Momentum } \\
\text { of the right } \\
\text { lead leg }\end{array}$ & 5 \\
\hline $\begin{array}{l}\text { Statistically } \\
\text { Significant }\end{array}$ & $\because \cdot r$ & $v .91$ & $9 r$ & $9 \leqslant$ & $9 \vee$ & $\mathrm{Cm}$ & $\begin{array}{l}\text { Height of } \\
\text { the COM }\end{array}$ & 6 \\
\hline $\begin{array}{l}\text { Not } \\
\text { significant }\end{array}$ & $.1 \leqslant$ & $\varepsilon . \cdots$ & Trt & TVA & $\varepsilon \cdot \wedge$ & $\% / \mathrm{s}$ & $\begin{array}{l}\text { Angular } \\
\text { velocity of } \\
\text { the right } \\
\text { knee joint }\end{array}$ & 7 \\
\hline $\begin{array}{l}\text { Statistically } \\
\text { Significant }\end{array}$ & $\because+1$ & $9 .$. & $9 \leqslant$ & $1 \cdot \varepsilon$ & $11 \mathrm{r}$ & o & $\begin{array}{l}\text { Left elbow } \\
\text { joint angle }\end{array}$ & 8 \\
\hline $\begin{array}{l}\text { Statistically } \\
\text { Significant }\end{array}$ & $\because r$ & $v_{.}$. & 110 & 119 & iro & o & $\begin{array}{l}\text { Left } \\
\text { support } \\
\text { ankle joint } \\
\text { angle }\end{array}$ & 9 \\
\hline $\begin{array}{l}\text { not } \\
\text { significant }\end{array}$ &. Ir & $\varepsilon . Y 7$ & 10r & 109 & $|v|$ & o & $\begin{array}{l}\text { Left } \\
\text { support } \\
\text { knee joint } \\
\text { angle }\end{array}$ & 10 \\
\hline
\end{tabular}

$*$ Sig.(p.value) $<0.05$

Table (1) shows that (p.Value) for Friedman's test below 0:05 biomechanical variables in the left front support (touchdown) . The differences between all research's measurements are significant with statistical differences.

Discussion of front left support (moment of touchdown) for subject runners
Table (2) show the mean velocity of the COM at the left leg touchdown for sprinters $(9.84 \mathrm{~m} / \mathrm{s})$, the velocity decreased during pull-resisted runs $(15 \%$ of $\mathrm{BM})$, to (9.31 $\mathrm{m} / \mathrm{s})$ and $(8.88 \mathrm{~m} / \mathrm{s})$ at pullresisted runs of $20 \%$ of body mass. The velocity of the COM, with $15 \%$ and $20 \%$ of $\mathrm{Bm}$ pull-resisted runs, decreased more than unresisted sprint, because the 
higher the resistance, the lower the velocity of the runners.

On one hand, the higher the resistance, the increase in the breaking force, which leads to loss of velocity. On the other hand, the horizontal reaction force increased because of the increased weight contact with the ground by resistance which required more energy production to encounter ground reaction force during touchdown.

Table (2) presents the average ground contact time in un-resisted sprint $(0.047 \mathrm{~s})$, increase to $(0.056 \mathrm{~s})$ in pullresisted runs of $15 \%$ of $\mathrm{BM}$ and $(0.064 \mathrm{~s})$ in $20 \%$ of BM. The researcher believes that there must be a pre-activation of muscles at ground contact, which increased at foot placement and lean of knee joint until the runner's center of mass is perpendicular on the ground.

The runner's ability for controlled resisted foot placement and toe-up influence the touchdown time and freezing, as confirmed by María Asunción Martínez (2015), a weighted sled reduced the athlete's stride length, stride frequency and sprint performance, increased ground contact time and the forward lean of the trunk) 9:140).

Table (2) shows the averages of the horizontal distance between toe-off and $\mathrm{COM}$ in pull resisted runs was $(41 \mathrm{~cm})$, reduced to $(35 \mathrm{~cm})$ in pull-resisted runs of $15 \%$ of $\mathrm{BM}$, and $(32 \mathrm{~cm})$ of $20 \%$ of the BM. The horizontal distance between toe and COM reduced in pull-resisted runs of $15 \%$ and $20 \%$ of body mass. The researcher believes that the horizontal distance between touchdown and COM shouldn't exaggeratedly increase because it disturb the movement of hips (COM) to rapidly transfer over foot support point.

Table (2) also shows the average momentum of left arm in un-resisted runs was $(5.47$ $\mathrm{kg} / \mathrm{s} 2)$ reduced to $(4.31 \mathrm{~kg} / \mathrm{s} 2)$ in pull-resisted runs of $15 \%$ and to $(3.25 \mathrm{Kg} / \mathrm{s} 2)$ of $20 \%$. Loren Seagrave, Ralph Mouchbahani, Kevin O'Donnell (2009)confirmed that biomechanics have contended that the arms balance the forces of the legs to maintain the body in the proper alignment. (1:21), 
Table (2) shows that the average momentum of the left (lead) leg in un-resisted runs $(12.78 \mathrm{~kg} / \mathrm{s} 2)$, reduced to $(10.98 \mathrm{~kg} / \mathrm{s} 2)$ in pull-resisted runs of $15 \%$ of $\mathrm{BM}$, and $(8.12$ $\mathrm{kg} / \mathrm{s} 2$ ) of $20 \%$ of BM. The average height of COM in pullresisted runs was $(97 \mathrm{~cm})$, reduced to $(95 \mathrm{~cm})$ in pullresisted runs of $15 \%$ and (94 $\mathrm{cm})$ of $20 \%$ of BM. In the researcher's point of view that there is a relation between $\mathrm{COM}$ and horizontal distance between toe and COM, although this distance increased in un-resisted runs more than pull-resisted runs, the COM decreased in pullresisted runs more than unresisted runs.

The researcher believes that the more reduction in the knee joint angle, the COM decreased as per the results of table (2) as the average of support knee joint angle in unresisted runs was $\left(171^{\circ}\right)$, reduced to $\left(159^{\circ}\right)$ in pullresisted runs of $15 \%$ of $\mathrm{BM}$ and $\left(152^{\circ}\right)$ in $20 \%$ of BM.

The researcher also believes that the leg easily swings backward to the buttocks to save time and for Results of propulsion suitable biomechanical conditions for muscles relaxation, as the hamstring leave the heel to the buttocks concede with the forward extension of the thighs and the lower leg stay tightly bend towards the thigh to minimize the inertia for the swing leg to take its suitable position to effectively transfer in the forward swing.

Results show that the average of angular velocity of the right knee joint (lead leg) in un-resisted runs was $\left(408^{\circ} / \mathrm{s}\right)$, reduced to $(378 \%$ s) in pullresisted runs of $15 \%$ of $\mathrm{BM}$, and $(326 \%)$ of $20 \%$ of BM. The results also show that the average support ankle joint angle in un-resisted runs was $125^{\circ}$, reduced to $\left(119^{\circ}\right)$ in pullresisted runs of $15 \%$ of $\mathrm{BM}$, and $\left(115^{\circ}\right)$ in $20 \%$ of BM. The researcher believes that the start of touchdown results in pawing action of outside toe, so that the arc of the foot restores elastic energy, which raised the heel to make the leg muscles works with its full extension. This angle reduced when COM is perpendicular on the support foot. 
Table (3)

Significant differences of biomechanical variables of unresisted runs and pull-resisted runs $(15 \%-20 \% \mathrm{BM})$ at propulsion (push-off) $\mathrm{N}=6$

\begin{tabular}{|c|c|c|c|c|c|c|c|c|}
\hline \multirow[b]{2}{*}{ Significance } & \multirow[b]{2}{*}{$\begin{array}{c}\text { Sig. } \\
\text { )p.value( }\end{array}$} & \multirow[b]{2}{*}{$\begin{array}{c}\text { Friedman's } \\
\text { test } \\
\text { (X2) }\end{array}$} & \multicolumn{3}{|c|}{ Mean } & \multirow[b]{2}{*}{$\begin{array}{c}\text { Measuring } \\
\text { units }\end{array}$} & \multirow[b]{2}{*}{ Variables } & \multirow[b]{2}{*}{$\mathbf{S}$} \\
\hline & & & $\begin{array}{c}\text { Pull- } \\
\text { resisted } \\
\text { runs of } \\
20 \% \text { of } \\
\text { BM } \\
\end{array}$ & $\begin{array}{c}\text { Pull- } \\
\text { resisted } \\
\text { runs of } \\
15 \% \text { of } \\
\text { BM } \\
\end{array}$ & $\begin{array}{l}\text { Un- } \\
\text { resisted } \\
\text { runs }\end{array}$ & & & \\
\hline $\begin{array}{l}\text { Statistically } \\
\text { Significant }\end{array}$ & $\because \wedge 0$ & N.M & $\wedge, 9 \wedge$ & $9,7 r$ & $9, \wedge \top$ & $(\mathrm{m} / \mathrm{s})$ & $\begin{array}{c}\text { Velocity of } \\
\text { the COM }\end{array}$ & 1 \\
\hline $\begin{array}{l}\text { Statistically } \\
\text { Significant }\end{array}$ & $\because \cdot 1$ & $11 . \mathrm{rV}$ & $\leqslant 9$ & or & 07 & $(\mathrm{~cm})$ & $\begin{array}{c}\text { Left knee } \\
\text { joint height }\end{array}$ & 2 \\
\hline $\begin{array}{l}\text { Statistically } \\
\text { Significant }\end{array}$ & $\because+1$ & $11.0 \mathrm{~V}$ & vo & $\vee \wedge$ & $\wedge 1$ & $(\mathrm{~cm})$ & $\begin{array}{l}\text { Right knee } \\
\text { joint height }\end{array}$ & 3 \\
\hline $\begin{array}{l}\text { Statistically } \\
\text { Significant }\end{array}$ & $\because \cdot 1$ & T.M & $0,7 r$ & 97,7 & r, & ) $\mathrm{kgms} / \mathrm{s})^{2}$ & $\begin{array}{l}\text { Momentum of } \\
\text { the right arm }\end{array}$ & 4 \\
\hline $\begin{array}{l}\text { not } \\
\text { significant }\end{array}$ & $\because v$ & ט.r. & $M, M$ & $\Lambda 9,1 r$ & $1 \leq, 1 \leq$ & $(\mathrm{kgms} / \mathrm{s})^{2}$ & $\begin{array}{c}\text { Momentum } \\
\text { of the right } \\
\text { lead leg }\end{array}$ & 5 \\
\hline $\begin{array}{l}\text { Statistically } \\
\text { Significant }\end{array}$ & $\because \cdot 1$ & $9 . \leqslant 1$ & 90 & $9 \wedge$ & $1 \cdot r$ & $(\mathrm{~cm})$ & $\begin{array}{c}\text { Height of } \\
\text { COM }\end{array}$ & 6 \\
\hline $\begin{array}{l}\text { Statistically } \\
\text { Significant }\end{array}$ & $\because r$ & $\wedge . \leqslant \varepsilon$ & $\varepsilon V$ & 01 & 07 & $(\mathrm{~cm})$ & $\begin{array}{c}\text { Horizontal } \\
\text { distance between } \\
\text { support toe and } \\
\text { COM } \\
\end{array}$ & 7 \\
\hline $\begin{array}{l}\text { Statistically } \\
\text { Significant }\end{array}$ & $\because \cdot 1$ & IY... & . vo, & $\cdot 7 \wedge$, & $\cdot 7 r$, & (s) & $\begin{array}{l}\text { Propulsion } \\
\text { time (push- } \\
\text { off time) }\end{array}$ & 8 \\
\hline $\begin{array}{l}\text { not } \\
\text { significant }\end{array}$ & $\because \cdot V$ & $0 . \mu$. & TAV & $\varepsilon \varepsilon r$ & $\leqslant 7$. & $\left.{ }^{\circ}\right) \mathrm{s}($ & $\begin{array}{c}\text { Angular } \\
\text { velocity of the } \\
\text { right knee } \\
\text { joint (lead leg) }\end{array}$ & 9 \\
\hline $\begin{array}{l}\text { not } \\
\text { significant }\end{array}$ & $\because v$ & $0 . \leqslant 1$ & 1.1 & 97 & 10 & $\left({ }^{o}\right)$ & $\begin{array}{c}\text { Right elbow } \\
\text { angle }\end{array}$ & 10 \\
\hline $\begin{array}{l}\text { Statistically } \\
\text { Significant }\end{array}$ & $\because \cdot 1$ & $11 . \mathrm{rV}$ & $\wedge \wedge$ & $9 \wedge$ & $1 \cdot r$ & $\left({ }^{\circ}\right)$ & $\begin{array}{c}\text { 11. Left } \\
\text { support ankle } \\
\text { joint angle }\end{array}$ & 11 \\
\hline $\begin{array}{l}\text { Statistically } \\
\text { Significant }\end{array}$ & $\because r$ & V.ru & 104 & 107 & rד & $\left({ }^{\circ}\right)$ & $\begin{array}{c}\text { Left support } \\
\text { knee joint angle }\end{array}$ & 12 \\
\hline $\begin{array}{l}\text { not } \\
\text { significant }\end{array}$ & $\because v$ & $0 . \leqslant T$ & 00 & or & $\leqslant 9$ & $\left({ }^{\circ}\right)$ & $\begin{array}{c}\text { Right lead } \\
\text { knee joint } \\
\text { angle } \\
\end{array}$ & 13 \\
\hline $\begin{array}{l}\text { Statistically } \\
\text { Significant }\end{array}$ & $\because \cdot 1$ & Tr & 9,91 & $9, \cdot 1$ & $\wedge, 7 r$ & (Newton/s) & Propulsion & 14 \\
\hline $\begin{array}{l}\text { Statistically } \\
\text { Significant }\end{array}$ & $\because \cdot 1$ & ir... & vo & $\vee q$ & NT & $\left({ }^{\circ}\right)$ & $\begin{array}{c}\text { Angle } \\
\text { between trunk } \\
\text { and lead thigh }\end{array}$ & 15 \\
\hline
\end{tabular}

Sig. $($ p.value) $<0.05$ 


\section{6}

Table (3) shows that (p.Value) for Friedman's test below 0.05 biomechanical variables in the propulsion (push-off). The differences between all research's measurements are significant with statistical differences.

\section{Results of propulsion}

Table (3) shows that the average velocity of $\mathrm{COM}$ in un-resisted runs was $(9.86 \mathrm{~m} / \mathrm{s})$, reduced in pull-resisted runs of $15 \%$ of body mass to $(9.62 \mathrm{~m} / \mathrm{s})$ and $(8.98 \mathrm{~m} / \mathrm{s})$ of $20 \%$ of body mass. The rate of reduction in velocity of the COM in pullresisted runs of $15 \%$ of body mass and un-resisted runs was $(0.24 \mathrm{~m} / \mathrm{s})$. The rate of reduction of velocity in pullresisted runs of $15 \%$ of body mass and un-resisted runs was $(0.88 \mathrm{~m} / \mathrm{s})$.

These results show that the velocity of COM reduced by the increase in resistance which shouldn't affect the sprint technique, otherwise it will unbalance the lower and upper limbs joint angle as shown in table (3) that the average height of COM in pullresisted runs was $(102 \mathrm{~cm})$, reduced in pull-resisted runs of $15 \%$ of body mass to $(98 \mathrm{~cm})$, reduced in pull-resisted runs of
$20 \%$ of body mass to $(95 \mathrm{~cm})$. The rate of reduction of the height of COM in pull-resisted runs of $15 \%$ of body mass was $(4 \mathrm{~cm})$ and $(7 \mathrm{~cm})$ in pullresisted runs of $20 \%$ of body mass, since the resistance pulls the runner backward in the time he try to move forward, however by increasing resistance, energy production significantly increased by extension and contraction of the muscles which is obvious in the ligaments, and tendons so that it affects the range of motion of the lower extreme joint angle as shown in table (3) since results shows that the average of left knee joint (lead) in un-resisted runs was $(56 \mathrm{~cm})$ and $(52 \mathrm{~cm})$ in pull-resisted runs of $15 \%$ of body mass and $(49 \mathrm{~cm})$ in pull-resisted runs of $20 \%$ of body mass. Support knee joint height reduced by increasing resistance as shown in table (3).

Results of table (3) show that the average height of the lead knee joint (right) in unresisted runs was $(81 \mathrm{~cm})$ and $(78 \mathrm{~cm})$ in pull-resisted runs of $15 \%$ of body mass, and (75 $\mathrm{cm})$ of $20 \%$ of the body mass. The researcher believes that lead knee joint angle affects 
the height of the knee joint as the increase in the angle reduced the height of the knee and vice verse as shown in table (3) were the average lead knee joint angle in un-resisted runs was $(49 \mathrm{~cm})$ and $(53 \mathrm{~cm})$ in pull-resisted runs of $15 \%$ of body mass and $(55 \mathrm{~cm})$ in $20 \%$ of the body mass.

The results also show that the average of angular velocity of lead knee joint in un-resisted runs was $(360 \%)$, reduced to pull-resisted runs of $15 \%$ of body mass to $(342 \%)$ and $\left(317^{\circ} \mathrm{s}\right)$ of $20 \%$ of the body mass. Results show that the average of momentum of left arm in un-resisted runs was $(7.31 \mathrm{~kg} / \mathrm{s} 2)$, reduced in pullresisted runs of $15 \%$ of body mass to $(6.96 \mathrm{~kg} / \mathrm{s} 2)$ and $(5.62$ $\mathrm{kg} / \mathrm{s} 2$ ) in pull-resisted runs of $20 \%$ of body mass. Table (3) show that the average of the angle of the left support ankle joint was $\left(103^{\circ}\right)$, reduced to $\left(98^{\circ}\right)$ in pull-resisted runs of $15 \%$ of body mass and $\left(88^{\circ}\right)$ in pull-resisted runs of $20 \%$ of body mass.

Results of table (3) show that the horizontal velocity between support toe and COM (drive) was $(56 \mathrm{~cm})$ in unresisted runs, reduced to
$(51 \mathrm{~cm})$ in pull-resisted runs of $15 \%$ of body mass, and (49 $\mathrm{cm})$ in $20 \%$ of body mass. The researcher believes that the distance affects the height of the COM and angle of propulsion as the increase in the distance will leads to decrease in the toe-off angle and vice verse. Results shows that the propulsion time in unresisted runs was $(0.062 \mathrm{~s})$, increased in pull-resisted runs of $15 \%$ of body mass to $(0.068 \mathrm{~s})$ and $(0.075 \mathrm{~s})$ in $20 \%$ of the BM.

The propulsion time increased by pull resistance, as it increases the total stride time, and negatively affects the velocity. The average angle between the trunk and lead thigh in un-resisted runs was $\left(83^{\circ}\right)$, reduced to $\left(79^{\circ}\right)$ in pullresisted runs of $15 \%$ of body mass and $\left(75^{\circ}\right)$ in $20 \%$ of the body mass. The angle reduced by increasing resistance so that the ability to increase drive distance by good range of motion of hips extension will allow the longer application of force, according to María Asunción Martínez (2015) that a weighted sled reduced the athlete's stride length, stride frequency and sprint 
performance, increased ground contact time and the forward lean of the trunk(9:140), which was observed on the angular velocity of the lead knee joint which was $\left(460^{\circ} / \mathrm{s}\right)$ in un-resisted runs and $(442 \%)$ in pull-resisted run of $15 \%$ of $\mathrm{BM}$, and $\left(387^{\circ} / \mathrm{s}\right)$ of $20 \%$ of the BM.

From table (3) we can noticed that the average propulsion in un-resisted was $(8.62 \mathrm{n} / \mathrm{s})$, increased to $(9.01$ $\mathrm{n} / \mathrm{s}$ ) in pull-resisted runs of $15 \%$ of $\mathrm{BM}$, and $(9.98 \mathrm{n} / \mathrm{s})$ of
$20 \%$ of BM. Push-off is the force $\times$ time to increase acceleration and the direction refers to the direction of acceleration as backward drive will push the runner forward faster according to the 3rd law of Newton "For every action there is an equal and opposite re-action." Propulsion is related to time and changes in body momentum, increasing resistance affects propulsion time which was observed in increased propulsion.

\section{Flight phase results}

Table ( $\varepsilon)$

Significant differences of biomechanical variables of un-resisted and pull-resisted runs $(15 \%-20 \% \mathrm{BM})$ at flight (flight stage) $\mathrm{N}=6$

\begin{tabular}{|c|c|c|c|c|c|c|c|c|}
\hline \multirow{2}{*}{ Significance } & \multirow[b]{2}{*}{$\begin{array}{c}\text { Sig. } \\
\text { )p.value( }\end{array}$} & \multirow[b]{2}{*}{$\begin{array}{c}\text { Friedman's } \\
\text { test } \\
\text { (X2) }\end{array}$} & \multicolumn{3}{|c|}{ Mean } & \multirow[b]{2}{*}{$\begin{array}{c}\text { Measuring } \\
\text { units }\end{array}$} & \multirow[b]{2}{*}{ Variables } & \multirow[b]{2}{*}{$\mathbf{S}$} \\
\hline & & & $\begin{array}{c}\text { Pull- } \\
\text { resisted } \\
\text { runs of } \\
20 \% \text { of } \\
\text { BM } \\
\end{array}$ & $\begin{array}{c}\text { Pull- } \\
\text { resisted } \\
\text { runs of } \\
15 \% \text { of } \\
\text { BM } \\
\end{array}$ & $\begin{array}{l}\text { Un- } \\
\text { resisted } \\
\text { runs }\end{array}$ & & & \\
\hline $\begin{array}{l}\text { Statistically } \\
\text { Significant }\end{array}$ & $\because \cdot 1$ & $1 \cdot . r r$ & 9.19 & 9.95 & 10.68 & ) $\mathrm{m} / \mathrm{s}($ & $\begin{array}{l}\text { Velocity of } \\
\text { the COM }\end{array}$ & 1 \\
\hline $\begin{array}{l}\text { Not } \\
\text { significant }\end{array}$ & $\because 1 \leq$ & $1 . \cdots$ & .110 & .110 & ד & )$s($ & Flight time & 2 \\
\hline $\begin{array}{l}\text { Statistically } \\
\text { Significant }\end{array}$ & $\because .0$ & ৭.Ar & 71 & 74 & 78 & )$^{\circ}($ & $\begin{array}{c}\text { Angle } \\
\text { between } \\
\text { right and } \\
\text { left thigh } \\
\text { joints at } \\
\text { top of } \\
\text { flight }\end{array}$ & 3 \\
\hline \multicolumn{9}{|c|}{$\begin{array}{l}\text { *Sig p.value } \cdot \bullet> \\
\text { Table (4) shows that } \\
\text { (p.Value) for Friedman's test } \\
\text { below } 0.05 \text { biomechanical } \\
\text { variables at the flight moment }\end{array}$} \\
\hline
\end{tabular}


Results in table (4) show the average velocity of center of gravity was $10.68 \mathrm{~m} / \mathrm{s}$ in unresisted sprint, reduced to $9.95 \mathrm{~m} / \mathrm{s}$ in pull-resisted runs of $15 \%$ of $\mathrm{BM}$, and $9.19 \mathrm{~m} / \mathrm{s}$ in pull-resisted runs of $20 \%$ of body mass. Results show reduction of center of mass velocity at flight in pullresisted runs of $15 \% \& 20 \%$ of $\mathrm{BM}$ because the flight time is the vertical distance, in which $\mathrm{COM}$ is moved at the moment the runner's body is on the air, where biomechanical principles (drive velocity, height of COM, drive angle and air resistance) controls this moment.

The average flight time was in un-resisted runs $(0.126 \mathrm{~s})$, reduced to $(0.115 \mathrm{~s})$ in pull-resisted runs of $15 \%$ of body mass and $(0.105 \mathrm{~s})$ in pull- resisted runs of $20 \%$ of body mass. Results of table (4) that the average angle between the right and left thigh joint in unresisted sprint was $\left(78^{\circ}\right)$, reduced to $\left(74^{\circ}\right)$ in pull-resisted runs of $15 \%$ of $\mathrm{BM}$, and $\left(71^{\circ}\right)$ in pull-resisted runs of $20 \%$ of body mass. The angle between the thighs reduced in pullresisted runs of $15 \%$ and $20 \%$ of body mass. In the researcher's point of view this is because of the drive angle and propulsive time of support leg, the reduction of the angular velocity of the swinging knee joint as flight height stopped at this body position before the instant of flight. At propulsion, the runners' flight method is unchangeable until touchdown with the other foot.

\section{Results of instant of right support (touchdown)}

\section{Table (5)}

Significant differences of biomechanical variables of un-resisted and pull-resisted runs (15\%-20\% BM) at right front support (touchdown) $\mathrm{N}=6$

\begin{tabular}{|c|c|c|c|c|c|c|c|c|}
\hline \multirow[b]{2}{*}{ Significance } & \multirow[b]{2}{*}{$\begin{array}{c}\text { Sig. } \\
\text { )p.value( }\end{array}$} & \multirow[b]{2}{*}{$\begin{array}{c}\text { Friedman's } \\
\text { test } \\
(\mathrm{X} 2)\end{array}$} & \multicolumn{3}{|c|}{ Mean } & \multirow[b]{2}{*}{$\begin{array}{c}\text { Measuring } \\
\text { units }\end{array}$} & \multirow[b]{2}{*}{ Variables } & \multirow[b]{2}{*}{$\mathbf{S}$} \\
\hline & & & $\begin{array}{c}\text { Pull- } \\
\text { resisted } \\
\text { runs of } \\
20 \% \\
\text { of } \mathrm{BM}\end{array}$ & $\begin{array}{c}\text { Pull- } \\
\text { resisted } \\
\text { runs of } \\
15 \% \text { of } \\
\text { BM }\end{array}$ & $\begin{array}{l}\text { Un- } \\
\text { resisted } \\
\text { runs }\end{array}$ & & & \\
\hline $\begin{array}{l}\text { not } \\
\text { significant }\end{array}$ & $\cdot .71$ & $1 . \cdots$ & $\wedge . \vee \wedge$ & 9.14 & 9.71 & $\mathbf{m} / \mathbf{s}$ & $\begin{array}{l}\text { Velocity of } \\
\text { the COM }\end{array}$ & 1 \\
\hline $\begin{array}{l}\text { Statistically } \\
\text { Significant }\end{array}$ & $\because \cdot 1$ & 9.70 & $\leqslant 4$ & $\leqslant 9$ & or & $\mathrm{Cm}$ & $\begin{array}{l}\text { Right knee } \\
\text { joint height }\end{array}$ & 2 \\
\hline
\end{tabular}


Follow Table (5)

Significant differences of biomechanical variables of un-resisted and pull-resisted runs (15\%-20\% BM) at right front support (touchdown) $\mathrm{N}=6$

\begin{tabular}{|c|c|c|c|c|c|c|c|c|}
\hline \multirow[b]{2}{*}{ Significance } & \multirow[b]{2}{*}{$\begin{array}{l}\text { Sig. } \\
\text { )p.value( }\end{array}$} & \multirow[b]{2}{*}{$\begin{array}{c}\text { Friedman's } \\
\text { test } \\
\text { (X2) }\end{array}$} & \multicolumn{3}{|c|}{ Mean } & \multirow[b]{2}{*}{$\begin{array}{c}\text { Measuring } \\
\text { units }\end{array}$} & \multirow[b]{2}{*}{ Variables } & \multirow[b]{2}{*}{$\mathbf{S}$} \\
\hline & & & $\begin{array}{c}\text { Pull- } \\
\text { resisted } \\
\text { runs of } \\
20 \% \\
\text { of } \mathrm{BM}\end{array}$ & $\begin{array}{c}\text { Pull- } \\
\text { resisted } \\
\text { runs of } \\
15 \% \text { of } \\
\text { BM }\end{array}$ & $\begin{array}{l}\text { Un- } \\
\text { resisted } \\
\text { runs }\end{array}$ & & & \\
\hline $\begin{array}{l}\text { not } \\
\text { significant }\end{array}$ & $\because \cdot v$ & $0 . r r$ & 01 & $\leq \wedge$ & o. & $\mathrm{Cm}$ & $\begin{array}{l}\text { Left knee } \\
\text { joint height }\end{array}$ & 3 \\
\hline $\begin{array}{l}\text { Statistically } \\
\text { Significant }\end{array}$ & $\because \cdot r$ & $v_{.}$. & 0.11 & 7.11 & $0 . r r$ & $\mathbf{m} / \mathbf{s}$ & $\begin{array}{l}\text { Velocity of } \\
\text { left knee }\end{array}$ & 4 \\
\hline $\begin{array}{l}\text { not } \\
\text { significant }\end{array}$ & $\cdot \wedge 0$ & rr & v.11 & $v_{.} \cdot 1$ & 7.90 & $\mathrm{Kgm} / \mathrm{s}^{2}$ & $\begin{array}{l}\text { Momentum } \\
\text { of right } \\
\text { arm }\end{array}$ & 5 \\
\hline $\begin{array}{l}\text { not } \\
\text { significant }\end{array}$ & $\because 01$ & r & $9 . \cdot r$ & 18.9 & $\mid r \cdot . \wedge$ & $\mathrm{Kgm} / \mathrm{s}^{2}$ & $\begin{array}{l}\text { Momentum } \\
\text { of left leg }\end{array}$ & 6 \\
\hline $\begin{array}{l}\text { Statistically } \\
\text { Significant }\end{array}$ & $\because \cdot 1$ & $1 . .1 \mathrm{~V}$ & 9. & $9 r$ & 90 & $\mathbf{c m}$ & $\begin{array}{l}\text { Height of } \\
\text { COM }\end{array}$ & 7 \\
\hline $\begin{array}{l}\text { Statistically } \\
\text { Significant }\end{array}$ & $\because \cdot r$ & $\Lambda . \leqslant 7$ & r & $r \leq$ & rq & $\mathbf{c m}$ & $\begin{array}{l}\text { Horizontal } \\
\text { distance } \\
\text { between } \\
\text { toe and } \\
\text { COM }\end{array}$ & 8 \\
\hline $\begin{array}{l}\text { Statistically } \\
\text { Significant }\end{array}$ & $\because+1$ & 1. & rri & rvq & Orr & $\% / \mathrm{s}$ & $\begin{array}{l}\text { Angular } \\
\text { velocity of } \\
\text { the left } \\
\text { knee }\end{array}$ & 9 \\
\hline $\begin{array}{l}\text { Statistically } \\
\text { Significant }\end{array}$ & $\because \cdot \varepsilon$ & T.rr & 1.9 & 99 & 1.0 & o & $\begin{array}{l}\text { Right } \\
\text { elbow } \\
\text { angle }\end{array}$ & 10 \\
\hline $\begin{array}{l}\text { Statistically } \\
\text { Significant }\end{array}$ & $\because+1$ & $9 . \leqslant 1$ & ir. & Irr & |r| & o & $\begin{array}{l}\text { Angle of } \\
\text { right ankle } \\
\text { joint } \\
\text { (support) }\end{array}$ & 11 \\
\hline $\begin{array}{l}\text { Statistically } \\
\text { Significant }\end{array}$ & $\because+1$ & $9 . r r$ & 10. & 107 & 179 & o & $\begin{array}{l}\text { Angle of } \\
\text { right knee } \\
\text { joint }\end{array}$ & 12 \\
\hline $\begin{array}{l}\text { Statistically } \\
\text { Significant }\end{array}$ & $\because+1$ & Ir... & 0.7. & $\because .00$ & $\because \cdot \leqslant \wedge$ & $\mathbf{S}$ & $\begin{array}{l}\text { Ground } \\
\text { contact } \\
\text { time from }\end{array}$ & 13 \\
\hline $\begin{array}{l}\text { Statistically } \\
\text { Significant }\end{array}$ & $\because+1$ & Ir... & 1.69 & 1.91 & r.19 & $\mathbf{M}$ & $\begin{array}{l}\text { Average } \\
\text { stride } \\
\text { length }\end{array}$ & 14 \\
\hline $\begin{array}{l}\text { Statistically } \\
\text { Significant }\end{array}$ & r & $\Lambda . \leqslant 1$ & $\varepsilon .91$ & $\leq .71$ & $\leqslant .10$ & $\mathbf{S}$ & $\begin{array}{l}30 \text { meter } \\
\text { sprint } \\
\text { times }\end{array}$ & 15 \\
\hline
\end{tabular}

*Sig. (P-value $\cdot .0>($ 
Table (5) shows that $\mathrm{p}$ value for Friedman's test significance level 0.05 for biomechanical variables in right front support (touchdown). The differences between all research's measurements are significant with statistical differences.

Discussion of results of right support (touchdown)

Table (5) shows the average velocity of COM for un-resisted runs $(9.61 \mathrm{~m} / \mathrm{s})$, which reduced to $(9.12 \mathrm{~m} / \mathrm{s})$ with pull-resisted runs of $15 \%$ of $\mathrm{BM}$ and $(8.78 \mathrm{~m} / \mathrm{s})$ of $20 \%$ of BM. The velocity of COM of $15 \%$ of the BM in resistance training reduced more than unresisted runs to $(0.36 \mathrm{~m} / \mathrm{s})$ and $(0.83 \mathrm{~m} / \mathrm{s})$ of $20 \%$ of the BM. These values matches the results of Loren Seagrave, Ralph Mouchbahani, Kevin O'Donnell (2009), that the Ground Phase begins at touchdown and has two distinctly different aspects, the Front side Phase and the Backside Phase. The aim in the Front side Phase is to horizontally displace the centre of mass from touchdown through mid-stance to take-off in shortest time possible (1:2526).
Table (5) shows that average height of the right knee joint (support) was $52 \mathrm{~cm}$ in pull-resisted runs, reduced to $49 \mathrm{~cm}$ in pull-resisted runs of $15 \%$ of body mass and $46 \mathrm{~cm}$ in pull-resisted runs of $20 \%$ of body mass. The height of the $\mathrm{COM}$ in pull-resisted runs of $15 \%$ of body mass reduced $3 \mathrm{~cm}$ than un-resisted sprint. It reduced $6 \mathrm{~cm}$ during pullresisted runs of $20 \%$ of $\mathrm{BM}$ more than un-resisted sprint. The researcher believes that height of support knee joint has significant correlation to the height of the COM as table (5) shows that the average height of the COM in un-resisted sprint was $(95 \mathrm{~cm})$, reduced to $92 \mathrm{~cm}$ in pull-resisted runs of $15 \%$ of the $\mathrm{BM}, 90 \mathrm{~cm}$ in pullresisted runs of $20 \%$ of the $\mathrm{BM}$ in touchdown. Thigh muscles resist body inclination on the support toe and ankle muscles resists load, then in the drive phase the body start acceleration by lifting the ground and hips rapidly move across COM over the foot. Excessive breaking force should be avoided as mentioned in table (5), the average of the horizontal distance between toe and COM 
in un- resisted sprint $(39 \mathrm{~cm})$, reduced to $34 \mathrm{~cm}$ in pullresisted runs of $15 \%$ of body mass, and $31 \mathrm{~cm}$ in pullresisted runs of $20 \%$ of the BM. The horizontal distance between the toe and COM reduced in pull-resisted runs of $15 \%$ of BM more than unresisted sprint at a rate of $5 \mathrm{~cm}$.

The distance between toe and COM in pull-resisted runs of $20 \%$ of the body mass decreased more than in the unresisted runs at a rate of $8 \mathrm{~cm}$, observed on the stride length, as results shows that the average of stride length in unresisted runs was $(2.19 \mathrm{~m})$, reduced in pull-resisted runs of $15 \%$ of the BM to $(1.98 \mathrm{~m})$ and $1.79 \mathrm{~m}$ in pull-resisted runs of $20 \%$ of the BM, according to Martínez et. al (2011), "The literature had focused on the percentage of loss in maximal velocity in a sled-towing exercise", that is running velocity in pull-resisted runs significantly decreased from 4$22 \%$, stride length reduced at a rate of $17 \%$, as shown in 30 meter sprint time (10:8-24). Table (5) shows that average time of touchdown in unresisted sprint was (0.048s), increased in pull-resisted runs of $15 \%$ of body mass to $(0.055 \mathrm{~s})$ and $(0.065 \mathrm{~s})$ in pullresisted runs of $20 \%$ of $\mathrm{BM}$ as seen in the total stride time and 30 meter sprint times which was (4.15s) in un-resisted sprint and (4.61s) in pullresisted runs of $15 \%$ of $\mathrm{BM}$ and (4.91s) in pull-resisted runs of $20 \%$ of BM. Zafeiridis et al (2005) confirmed that sprint training with sled pulling improves acceleration performance in $0(-2) 0 \mathrm{~m}$.

Conclusion

and

\section{Recommendations:}

\section{Conclusions:}

Given the results of the biomechanical analysis of this study as well as the subject athletes, the author has reached to the following conclusion:

- There are statistically significant differences between un resisted runs and pullresisted runs $(15 \%$ and $20 \%$ of $\mathrm{BM})$ lead to increase touchdown time, which were (0.056 s) and (0.064 s) in Pullresisted runs $(10 \% \& 15 \%$ of $\mathrm{BM})$. Touchdown time of unresisted sprint was $(0.047 \mathrm{~s})$.

- Increasing pull-resisted runs leads to decrease running velocity, as the loss in velocity during pull-resisted runs $(15 \%$ 
and $20 \%$ of $\mathrm{BM})$ were $(0.46 \mathrm{~s})$ and (0.76s). Velocity time increased to $19 \%$ and $20 \%$ in un-resisted sprint for subject sprinters.

- There are statistically significant differences between un resisted runs and pullresisted runs $(15 \%$ and $20 \%$ of $\mathrm{BM})$ lead to decreasing the stride length during pullresisted runs, the average of stride length during un-resisted sprint was (2.19s) and during pull-resisted runs $(15 \%$ and $20 \%$ of BM) were (1.98) and $(1.79 \mathrm{~m})$ for subject sprinters.

- There are statistically significant differences between un resisted runs and pullresisted runs $(15 \%$ and $20 \%$ of $\mathrm{BM})$ lead to decrease the angle between the trunk and swinging leg and decreased its angular velocity which was observed in the flight time.

Recommendations:

Given the results of the biomechanical analysis of this study as well as the subject athletes, the researcher has made the following recommendations:-

- Using light pull-resisted runs and high velocity will helps in avoiding faults in sprint stride technique.
- Using pull-resisted runs, which enhance acceleration of runners.

- Taking into account the quantitative values of the biomechanical variables in various moments of sprint stride shown by this research.

- Further studies on the sprint stride with different pullresisted runs.

\section{References}

\section{1- IAAF RDC Cairo ‘ New} Studies in Athletics (Arabic Version) 1/2009 (p. 24.(

\section{2- Gamal Alaa El Aladdin} and Nahed Al-Sabaag, Metrology bases for enhancing physical, skillful and tactical performance of the athlets. Monchaat Al Maaref, Alexandria (2007)

3- Akira Ito, Koji Fukuda and Kota Kijima :Mid-phase sprinting movements of Tyson Gay and Asafa Powell in the $100-\mathrm{m}$ race during the 2007 IAAF World Championships in Athletics. By IAFF 23:2-r/، or , r...人_s.

4- Loren Seagrave: The second European sprints\& Hurdles university of Warwick, England 10-11 November 2012.

5- Milan Coh, Katja Tomazin: Kinematic analysis 
of the sprint start and acceleration from the blocks by IAAF21:3; 23-33 2006.

6- Oleg Nemtsev Foot Placement by Elite Sprinters During Bend Running, by IAAF, 26:1/2; 79-82, 2011 11P. Grimshaw A. Burden: Sport and

Exercise

Biomechanics,2007.

7- Zafeiridis A1, Saraslanidis $\mathbf{P}$, Manou V, Ioakimidis $\mathbf{P}$, Dipla K, Kellis S The effects of resisted sled-pulling sprint training on acceleration and maximum speed performance $\mathbf{J}$ Sports Med Phys Fitness. 2005 Sep;45(3):284-90

8- María Asunción MartínezValencia1, Salvador RomeroArenas2, José L.L. Elvira3 José María González-Ravé4, Fernando Navarro-
Valdivielso4, Pedro E,. Alcaraz1,2 Effects of Sled Towing on Peak Force, the Rate of Force Development and Sprint Performance During the Acceleration Phase Journal of Human Kinetics volume 46/2015, 139-148 DOI: $10.1515 /$ hukin - $\quad$ Sports Training .2015-Section III

9- Martínez-Valencia MA1, González-Ravé JM, SantosGarcía DJ, Alcaraz Ramón PE, Navarro-Valdivielso F, Interrelationships between different loads in resisted sprints, half-squat $1 \mathrm{RM}$ and kinematic variables in trained athletes- Eur J Sport Sci. 2014;14 Suppl 1:S18-24. doi: 10.1080/17461391.2011.63893

5. Epub Dec 122011 